\title{
FRESH INFORMASI KEAGAMAAN MELALUI MEDIA INSTAGRAM DALAM MENANGGAPI COVID-19 DI INDONESIA
}

\author{
Aras Satria Agusta, Nurdin Laugu \\ Pascasarja Interdisciplinary Islamic Studies UIN Sunan Kalijaga Yogyakarta \\ email: arassatria.agusta@gmail.com
}

\begin{abstract}
Abstrak
Artikel ini bertujuan untuk melihat fresh informasi keagamaan melalui media Instagram bagi masyarakat virtual dalam menanggapi fenomena Covid-19 di Indonesia. Metode yang digunakan dalam penulisan ialah kualitatif dengan analisis data menggunakan pendekatan fenomenologi, pengumpulan data melalui observasi media dan dokumentasi. Hasil analisis yang didapatkan ialah terjadi interaksi positif dan negatif pada penggunaan "instagram" sebagai fresh informasi keagamaan dalam menghadapi Covid-19, dan reaksi tersebut terimplementasi pada upaya pencegahan yang dilakukan masyarakat dalam menanggulangi Covid-19 dengan kembali mencari nilai dan fatwa-fatwa keagamaan sebagai tempat bertumpu dari peristiwa tersebut. Sementara beberapa informasi yang ada dimedia juga tidak terlepas dari hoax yang menimbulkan reaksi kecemasan dan ketakutan yang over terhadap masyarakat, maka perlu adanya filter terhadap suatu informasi yang disebar luaskan melalui media instagram.
\end{abstract}

\author{
Kata Kunci: \\ Informasi, virtual, \\ instagram, keagamaan, \\ Covid-19
}

\section{A. PENDAHULUAN}

Pesatnya perkembangan teknologi informasi dan komunikasi saat ini memudahkan setiap orang untuk mengakses segala informasi dengan instan. Teknologi saat ini telah digunakan dalam berbagai bidang seperti dunia pendidikan, ekonomi, politik, sosial, dan budaya. Tercatat dari hasil survei 2018 penggunaan Internet di Indonesia sebanyak 171,17 juta jiwa dari populasi penduduk Indonesia 264,16 juta orang (Laporan Survei Penetrasi \& Profil Perilaku Pengguna Internet Indonesia, 2018). Selaras dengan data itu, dalam teori McLuhan dinyatakan suatu konsep determinisme teknologi yang membawa suatu artian bahwa dalam setiap kejadian atau suatu tindakan yang dilakukan manusia merupakan pengaruh dari perkembangan teknologi. Selanjutnya dikatakan bahwa ekspolitasi dari teknologi komunikasi dalam penyampaian suatu informasi akan memperbaiki hubungan sensorik dalam komunitas masyarakat. Dengan memperbaiki hubungan tersebut maka akan dapat menentukan pandangan dunia dari setiap masyarakat. Hal itu akan menentukan suatu upaya baru dalam bentuk pengetahuan, struktural, serta peralatan sensori yang disesuaikan untuk menyerap realitas (Holmes, 2005). Realitas yang dimaksud ialah merupakan suatu fakta dimana masyarakat virtual memanfaatkan teknologi komunikasi untuk dijadikan suatu sumber dalam belajar, dan mendapatkan informasi sehingga merubah paradigma masyarakat memanfaatkan media baru tersebut. Dengan adanya penggunaan internet yang semakin banyak akan memunculkan media-media baru yang dapat digunakan untuk penyebaran informasi.

Sementara untuk melihat interaksi yang terjadi di media sosial terhadap suatu informasi dalam strukturnya maka, pendekatan oleh Van Dijk dimana media sosial merupakan platform media yang digunakan sebagai sarana untuk berbagai kegiatan maupun berkolaborasi yang berfokus pada eksistensi pengguna, akan melihat secara seksama terhadap fenomena fresh informasi keagamaan yang terjadi dalam menghadapi Covid-19, dan informasi tersebut diambil dari akun official instagram, instagram sendiri diambil 
berdasarkan pada data APJll yang menunjukkan adanya peningkatan pengguna instagram $17.8 \%$ pada 2018, selain itu pada instagram juga terdapat interaksi yang cepat terhadap suatu informasi, serta instagram merupakan salah satu media yang digunakan masyarakat untuk mengakses informasi selain facebook dan youtube. Selaras dengan itu Menurut Bambang, Instagram merupakan salah satu aplikasi dari smartphone yang khusus untuk media sosial yang merupakan salah satu media digital yang mempunyai fungsi hampir sama dengan twitter, facebook tetapi berbeda dari pengambilan foto dalam bentuk atau tempat untuk berbagi informasi terhadap penggunanya. Di instagram pengguna dapat berinteraksi dengan akun yang terdaftar, pengguna juga dapat mengirimkan like, comment, dan direct message, sehingga satu informasi dapat secara dinamis tersebar dengan kecepatan yang optimal antara individu ataupun kelompok-kelompok masyarakat virtual.

Sinergisme informasi di instagram dengan fenomena Covid-19 telah menggemparkan Indonesia menjadi suatu bentuk bagaimana informasi tersebut dapat diterima dan diolah oleh masyarakat virtual. Sehingga menimbulkan gejala dalam fenomena sosial yang dimulai dari informasi melalui media-media. Seperti dalam Covid-19 akan menyerang individu dengan gejala umum yang timbul antara lain demam, batuk dan sesak napas, pneumonia, sindrom pernapasan akut, gagal ginjal, dan dapat menyebabkan kematian (Pedoman Kesiapsiagaan Menghadapi Infeksi Novel Coronavirus (2019-NCoV), 2020). Ini merupakan suatu bentuk informasi yang kemudian dapat direspons oleh setiap masyarakat virtual yang tergabung dalam media sosial. Selain itu, Informasi ini memberikan suatu pengetahuan bagi masyarakat virtual mengenai kejadian tersebarnya covid-19 yang begitu cepat dan akut. Maka dengan adanya media sosial, masyarakat dapat memantau setiap perkembangan baik itu informasi tentang virus corona, pencegahannya, jumlah masyarakat yang terinfeksi dan bagaimana masyarakat kembali kepada fresh informasi keagamaan dalam upaya mencari pangkuan untuk menghadapi virus tersebut, sehingga akan menunjukkan terhadap pola apa yang dilakukan masyarakat dalam merespon terhadap suatu informasi.

\section{B. TINJAUAN TEORITIS}

\section{Masyarakat Virtual}

Media sosial membentuk sebuah hubungan masyarakat yang membuat terjadinya network society. Dalam teori McLuhan digambarkan dalam bentuk suatu konsep determinisme teknologi dimana teknologi tersebut membawa suatu artian bahwa dalam setiap kejadian atau suatu tindakan yang dilakukan manusia merupakan pengaruh dari perkembangan teknologi. Selanjutnya dinyatakan bahwa ekspolitasi dari teknologi komunikasi dalam penyampaian suatu informasi akan memperbaiki hubungan sensorik dalam komunitas masyarakat. Dengan memperbaiki hubungan tersebut maka dapat menentukan pandangan dunia dari setiap masyarakat. Pandangan itu akan menentukan suatu upaya baru dalam bentuk pengetahuan, struktural, serta peralatan sensori yang disesuaikan untuk menyerap realitas (Holmes, 2005). Sensori dimaksud ialah suatu perwujudan dalam bentuk network society yang kemudian memunculkan sebuah komunitas virtual. Sementara realitas merupakan suatu fakta dimana masyarakat virtual memanfaatkan teknologi komunikasi untuk dijadikan suatu sumber dalam belajar, dari hal ini akan bergeser pada paradigma dalam suatu informasi atau disebut sebagai fresh of informations yang melahirkan komunitas virtual.

Komunitas virtual menurut Wood dan Smith ialah masyarakat yang berbagi informasi dengan melalui perantara komputer (Nasrullah, 2017). Sedangkan menurut Van Dijk, komunitas virtual ialah perkumpulan masyarakat yang keberadaanya 
tidak diketahui secara fisik tetapi dapat ditemukan di internet (Van Djik, 2006). Dalam artian budaya baru pada komunitas virtual dalam berbagi informasi menjadi inklusi yang dapat memberi dampak penyeimbangan dan kemudahan masyarakat untuk berbagi dan publish beragam bentuk informasi melalui akun media sosial. Quentian Jones dalam artikelnya journal of computer-mediated communication memberikan beberapa karakteristik dari pada komunitas virtual seperti (1) Level minimum dalam interaksi (2) Komunikator bervariasi yang merujuk pada sebuah komunitas virtual harus terdiri dari partisipan beragam sehingga interaksi yang terjadi akan membentuk dan berkembang secara luas (3) Adanya ruang publik umum sebagai medium interaksi bagai anggota komunitas (4) Level minimum dari jumlah keanggotaan (Nasrullah, 2017).

Memahami hal tersebut secara lebih makro maka, komunitas virtual merupakan bagian masyarakat berjejaring (network society), hal ini dikarenakan sifat dari internet dan teknologi komunikasi dalam interaksi yang terdapat didalamnya menyebabkan individu sebagai pengguna memiliki kuasa penuh, begitu pula relasi secara universal bisa dilakukan oleh setiap pengguna di internet. Dalam artian komunitas virtual adalah sekumpulan individu terbentuk di jejaring internet kemudian menyebarkan suatu informasi yang ditampilkan melalui media sosial ataupun suatu individu yang dapat memanfaatakan media sosial sebagai space dalam berbagi dan menanggapi terhadap suatu informasi.

\section{Media Sosial}

Media sosial merupakan medium di internet yang memungkinkan pengguna mempresentasikan dirinya maupun berinteraksi, bekerja sama, berbagi, berkomunikasi dengan pengguna lain, dan membentuk ikatan sosial secara virtual. Menurut Mandibergh, media sosial merupakan media yang digunakan untuk menghasilkan konten. Menurut
Van Dijk, media sosial merupakan platform media yang digunakan sebagai sarana untuk berbagai kegiatan maupun berkolaborasi yang berfokus pada eksistensi pengguna. Oleh karena itu, media sosial dapat disebutkan sebagai fasilitator online yang menghubungkan interaksi antar pengguna (Nasrullah, 2017).

Dalam artian, media sosial merupakan mediasi yang menghubungkan antara manusia dalam berinteraksi melalui jejaring internet, seperti adanya kegiatan interaksi antar pengguna, berbagi informasi, ataupun berkolaborasi dalam suatu pengetahuan, sehingga kegiatan interaksi tersebut membuat suatu bentuk baru komunikasi dua arah. Komunikasi dua arah dalam bentuk media sosial dimaksud ialah individu sebagai pengguna aktif dapat berinteraksi dengan individu lainnya dalam bentuk call, voicenote, video call, live content media social,and message. Kegiatan tersebut merupakan dekonstruksi dari kegiatan interaksi sosial secara konvensional, kemajuan dalam hal ini menggambarkan suatu fenomena dalam masyarakat virtual. Sementara menurut Baudrillard dalam masyarakat virtual terjadi suatu konsep simulasi, simulasi yang dimaksud ialah suatu model-model yang cermat, dalam artian sederhana diartikan sebagai suatu upaya untuk menghadirkan yang sebelumnya belum ada (Baurdrillard, 1983).

Sementara instagram merupakan salah satu aplikasi media sosial yang populer dikalangan user pada saat ini, dimana instagram berasal dari dua kata yaitu Insta yang artinya instan, kata instan yang berarti bahwa instagram akan menampilkan foto-foto secara instan seperti polaroid di dalam tampilannya. Sedangkan kata "Gram" berasal dari kata "Telegram" yang berarti mempunyai cara kerja untuk mengirimkan informasi kepada orang lain dengan cepat, seperti halnya dengan instagram yang dapat mengunggah foto, video dengan menggunakan jaringan internet, sehingga informasi yang akan disampaikan dapat diterima 
dengan cepat. Oleh karena itu istilah "Instagram" dapat mengarah pada kata "Instan-Telegram" (Sari, 2017). Menurut Bambang, Instagram merupakan sebuah aplikasi dari Smartphone yang khusus untuk media sosial yang merupakan salah satu dari media digital yang mempunyai fungsi hampir sama dengan twitter, namun perbedaannya terletak pada pengambilan foto dalam bentuk atau tempat untuk berbagi informasi terhadap penggunanya (Atmoko \& Dwi, 2012).

Instagram mempunyai banyak fungsi, selain untuk mengembangkan kreatifitas para pengguna, instagram juga memberikan informasi terupdate kepada penggunanya, baik itu informasi yang di unggah dari akun lembaga atau organisasi dengan berbagai informasi yang ada di dalamnya seperti informasi tentang pendidikan, kesehatan, agama, dan lain-lain sampai informasi yang diunggah sendiri oleh akun pribadi seperti informasi tentang keseharian seseorang yang diunggah dalam bentuk foto dan video. Dalam Instagram menggunakan istilah Following dan followers dalam pertemanan. Following berarti mengikuti pengguna lain dan followers berarti pengguna lain yang mengikuti akun. Setiap pengguna dapat berkomunikasi dengan cara memberikan komentar pada postingan pribadi ataupun akun lembaga lainnya dan memberikan respon dengan like terhadap foto dan video yang dibagikan.

\section{Fresh Informasi dalam nilai Sosial dan Keagamaan}

Informasi menjadi bagian yang sangat dibutuhkan dalam media sosial, Agama adalah ajaran yang mengatur hubungan antara manusia dengan tuhannya, manusia dengan manusia lainnya dan antara manusia dengan alam lingkungannya. Dari generasi informasi dan kebutuhan pengguna dalam mendapatkan suatu informasi tentunya tidak terlepas dari suatu pendekatan sosial. Dalam hal ini sosial yang dimaksud ialah generasi millennials dalam tataran ruang publik yang mempengaruhi terhadap perilaku generasi tersebut. Era keterbukaan informasi saat ini atau disebut masyarakat post-industrial sangat kentara terasa akan gejolak perubahan perilaku suatu individu atau kelompok.

Di Indonesia sendiri perubahan sosial telah menyentuh performance di segala kelas masyarakat, perubahan gaya hidup dan perilaku sosial ini terjadi sangat luas dan berkembang secara dinamis pada generasi millennials atau generasi muda yang merupakan pionir perubahan itu sendiri. Sementara ruang publik merupakan suatu konsep teoritis yang dibangun oleh Jurgen Habermas berfokus pada suatu kajian historis terhadap kritis sebagai feedbaack dalam suatu realitas sosial. Menurut Habermas ruang publik merupakan suatu wilayah dalam kehidupan sosial yang memungkinkan setiap masyarakat dalam satu kawasan Negara berbicara dan terlibat dari berbagai silang pendapat serta secara bersama-sama dapat membentuk pendapat umum. Melalui kehadiran ruang publik, masyarakat diharapkan dapat mengorganisasikan diri untuk membangun pendapat umum dan melontarkan kritik.

Habermas sering menggunakan istilah tindakan komunikatif untuk menjelaskan mengapa individu dapat melakukan interaksi sosial dan mencapai tujuannya dengan syarat mereka dapat untuk mengharmonisasikan rencana bertindak berdasarkan defenisi situasi bersama (Sugihartini, 2014). Dalam perkembangan masyarakat post-industrial membangun ruang publik yang konstruktif dan produktif sebagai pilar dalam perubahan termasuk didalamnya digital natives yang merupakan subjek dari perubahan yang dapat dipahami dalam suatu tontonan dan suara budaya media, dalam artian generasi ini dengan nama lain dari generasi millennials yang tumbuh dan berkembang pada era teknologi informasi terutama pada media elektronik handphone dan internet, kemudian di dalamnya terbangun sistem networking yang mendominasi, sehingga perluasan dari pada suatu pemanfaatan 
informasi tidak terbatas pada ruang-ruang tertentu saja. Internet memungkinkan bagi setiap individu untuk mendapatkan akses informasi. Dimana internet menawarkan sebuah prototype bagaimana dunia virtual dapat diaplikasikan meningkatkan proses system untuk membuatnya lebih terbuka dan partisipatif (Dahlgren, 2000).

Dari ruang berjejaring tersebut akan timbul suatu fresh informasi yang memberikan beragam pengetahuan baru kepada masyarakat secara instan, efektif, dan cepat. Seperti pengetahuan terhadap informasi keagamaan, maka masyarakat dapat dengan mudah untuk mengetahui terhadap suatu ketentuan yang ada didalam agamanya, informasi tersebut bisa berupa postingan gambar dan ilustrasi lainnya sehingga menimbulkan gairah para followers di media sosial untuk mengetahui secara lanjut dari suatu postingan tersebut. Begitu pula informasi keagamaan yang memuat terhadap konsep agama dalam menyikapi setiap peristiwa termasuk peristiwa yang sedang melanda di Indonesia yakni Covid-19, dimana virus tersebut telah mewabah dan memakan korban yang begitu banyak seperti di Cina, Italia, Korea Selatan, dan termasuk di Indonesia dan negara lainnya, sehingga informasi keagamaan sebagai fresh untuk kembali kepada konsep dan pemahaman agama menjadi novelty yang membawa artian informasi yang bermakna, efektif dan efisien pada interaksi dalam media sosial seperti instagram dalam lainnya.

\section{Covid-19 dan Nilai Informasi di Media Sosial}

Informasi yang tersebar melalui media sosial "instagram" akan memberikan suatu pengetahuan bagi masyarakat secara umum, terlebih pada fenomena wabah Covid-19 yang melanda beberapa Negara termasuk Indonesia. Sekilas Novel Coronavirus (2019-nCoV) merupakan virus baru yang menyebabkan penyakit saluran pernapasan yang berasal dari Cina. Virus ini dapat menyebabkan penyakit ringan seperti, flu, batuk dan demam hingga penyakit berat seperti sesak napas, pneumonia, sindrom pernapasan akut, gagal ginjal hingga dapat menyebabkan kematian. Jangkauan usia yang terinfeksi tidak terbatas, hanya saja orang tua dan orang-orang yang memiliki riwayat penyakit seperti asma, diabetes dan penyakit jantung lebih mudah terinfeksi. Pencegahan yang dapat dilakukan oleh masyarakat agar masyarakat tidak terinfeksi virus ini adalah sebagai berikut (1) Sering cuci tangan pakai sabun (2) Menggunakan masker jika batuk dan pilek (3) Mengkonsumsi gizi seimbang, perbanyak makan sayur dan buah (4) Menjaga kontak dengan hewan (5) Rajin olahraga dan istirahat yang cukup (6) Jangan mengkonsumsi daging mentah (7) Jika batuk, pilek dan sesak nafas segera ke fasilitas kesehatan (Kementrian Kesehat. Republik Indones., 2020).

Informasi tersebut merupakan suatu bentuk pengetahuan dalam suatu Fenomena yang memberitakan suatu informasi berbasis pada pengetahuan bagi masyarakat untuk lebih mawasdiri dalam upaya menanggulangi tertularnya covid-19. Dilain sisi, informasi dalam bentuk media sosial juga menimbulkan respon positif maupun negative. Terhadap dampak positif informasi Covid-19 secara tidak langsung membuat suatu konsep penyerahan diri kepada agama, sehingga setiap masyarakat terutama umat Islam dapat memanfaatkan informasi tersebut sebagai bentuk pengetahuan keagamaan, sebaliknya informasi hoax akan berdampak negative terhadap informasi covid-19 juga memberikan rasa ketakutan, keresahan, dan kegaduhan di masyarakat. Dalam artian, sentiment yang terdapat di media sosial juga tidak terhindar dari informasi hoax sehingga rasa kecemasan semakin meningkat, sisi paling ekstrim terhadap postingan tersebut dapat berujung pada tindakan irasional yang dapat merugikan publik secara umum, kepanikan public inilah dampak buruk terhadap informasi dalam media sosial yang terimplementasi pada kehidupan nyata. 


\section{METODE PENELITIAN}

Dalam tulisan ini menggunakan metode kualitatif dengan paradigma interpretative untuk melihat fenomenologi yang terjadi, pendekatan ini digunakan dengan upaya peneliti dalam menyisihkan pandangan atau persepsi pribadinya secara semenatara agar dapat secara murni menangkap semua perasaan, pikiran, dan kesadaran dari objek yang diteliti (Pendit, 2003). Dalam hal ini, objek yang diteliti ialah media sosial instagram yang memuat postingan keagamaan dalam upaya pencegahan terhadap Covid-19 di Indonesia, fokus pada interaksi yang terjadi pada postingan tersebut.

Data didapatkan melalui observasi media dan dokumentasi, adapun rumusan masalah ialah "mengapa Instagram menjadi fresh informasi keagamaan dalam menghadapi Covid-19, dengan melihat interaksi pada komentar dari followers akun instagram dalam menanggapi informasi tersebut". Sementara analisis data dalam penelitian ini berdasarkan pada teori Miles dan Huberman yang dilakukan secara interaktif terhadap aktivitas dalam analisis data yang meliputi data reduction, data display and verification (Sugiyono, 2017). Uji Keabsahan Data dengan cara menggunakan model triangulasi data. Triangulasi dilakukan untuk mengukur apakah data yang telah dikumpulkan sesuai dengan penelitian, triangulasi yang digunakan ialah triangulasi waktu dimana dilakukan dengan cara pengecekan data observasi dan dokumentasi dalam waktu yang berbeda. Hal ini dilakukan karena peneliti akan memastikan validnya suatu data yang telah diperoleh atau dalam hal memperkuat data yang sudah didapatkan.

\section{HASIL DAN PEMBAHASAN}

Fresh informasi baru menunjukkan terdapat relasi antara masyarakat virtual/followers di Instagram saling merespon terhadap sebuah informasi, akun-akun Instagram tersebut berpusat pada peran followers yang tidak hanya semata sebagai objek penerima informasi, tetapi para followers memiliki peran signifikan dalam merespon ataupun berbagi suatu informasi. Peran aktif followers tersebut dalam memproduksi konten informasi ataupun mereproduksi informasi melalui fitur komentar yang memungkinkan terjadinya diskusi atapun dialog dan wacana aktif terkait isu yang disampaikan dalam konten unggahan.

Partisipasi tersebut secara tidak langsung mengatur arah aliran diskusi dan wacana yang berkembang, dalam artian bisa menempatkan para followers dalam beberapa peran seperti pemberi informasi, kontra informasi, dan sebagai pelengkap terhadap suatu informasi yang disampaikan. Ketiga hal tersebut merupakan suatu bentuk peran aktif para followers yang memungkinkan membawa suatu novelty baik dalam bentuk "bahasa/istilah", maupun kesadaran dalam memaknai suatu informasi.

Hal ini menunjukkan adanya suatu relasi dan komunikasi yang terintegrasi melibatkan banyak orang, sehingga media baru ini berbeda dari media lama seperti TV ataupun radio. Sementara tantangan dalam hal ini ialah berpusat pada literasi informasi di media baru, karena dengan meluas dan bebasnya suatu informasi maka informasi hoax juga semakin berkembang sehingga menimbulkan suatu reaksi kegaduhan di masyarakat. Dalam konteks ini, para followers yang menyikapi terhadap informasi mengenai fenomena wabah Covid-19 di Indonesia menjadi trending topik di beberapa media sosial salah satunya di Instagram, informasi tersebut secara tidak langsung juga memiliki suatu bentuk penyadaran pengetahuan keagamaan dalam menyikapi Covid-19 kepada masyarakat. Pada postingan akun Instagram @berbagisemangat memberikan nasehat seperti:

"kemungkinan engkau meninggal karena virus corona hanya $1 \%$ sedangkan kemungkinan engkau meninggal disetiap saat adalah 100\%. Maka 
senantiasa perbarui imanmu, senantiasa bertakwa kepada allah swt dan barang siapa yang bertakwa kepada allah swt niscaya cukup baginya".

Postingan ini mendapatkan respon positive dan negative dari masyarakat virtual, seperti respon yang disampaikan oleh akun @lydiabilyaswan

"contoh ni ya, kita beropini seperti itu tapi kita tidak aware sama covid-19 terus kita keluar-keluar tanpa was-was dan benar kita kena, kita kembali kerumah bertemu orang-orang terkasih, kebetulan imun kita kebal. Eh yang kena balita, gimana tu? kematian memang sudah tercatat di lauhul mahfudz tapi ada baiknya kita bertawakal kepada Allah swt meminta perlindungannya dan tetap ikuti peraturan dari pemerintah, insyaallah apapun yang terjadi kepada kita itu sudah ridho Allah SWT, kita sudah berupaya pencegahannya".

Komentar yang diberikan oleh @lydiabilyaswan menyatakan bahwa setiap manusia pasti akan mati namun hadirnya wabah Covid-19 bisa saja merubah takdir kematian manusia apabila mereka tidak mengikuti peraturan yang telah dibuat oleh pemerintah dan tidak mengikuti langkah-langkah pencegahan yang telah disampaikan. Berserah diri kepada Allah SWT bukan membuat kita menyerah dan tidak berusaha untuk menghindari virus Covid-19. Namun apabila kita telah berusaha mengikuti setiap aturan hasilnya kita kembali lagi dengan Allah SWT dan ridho dengan apa yang terjadi seterusnya.

Selain itu terdapat pula di postingan @indonesiabertauhid kajian Aa Gym tentang Covid-19

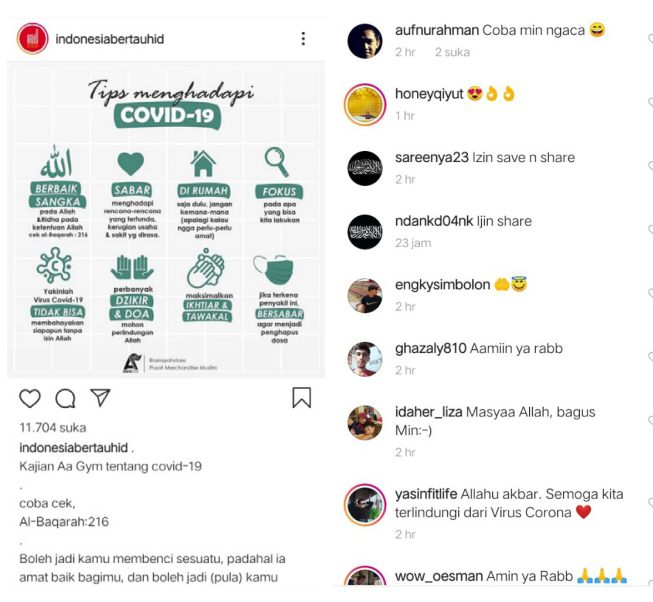

Gambar 1. Instagram Indonesia bertauhid

"boleh jadi kamu membenci sesuatu, padahal ia amat baik bagimu, dan boleh jadi (pula) kamu menyukai sesuatu, padahal ia amat buruk bagimu, Allah SWT mengetahui, sedangkan kamu tidak mengetahui. Kata Aa Gym makanya jangan sok tau, berbaik sangka aja sama Allah SWT. Try to find good things in everything that happen. Pake kacamata syukuran kita. Perasaan anxious wajar, karena Allah SWT menciptakan hal itu pada diri kita, supaya kita bisa waspada, dan memikirkan bagaimana caranya survive. Kejadian seperti ini sebenarnya menyadarkan kita, bahwa kita sebenarnya yang halu. Sering take it for grated nikmat-nikmat yang Allah SWT beri. 2 hari yang lalu, nyatanya kita tidak tahu bahwa hari ini kita akan hidup. Kita Cuma berasumsi akan hidup. Saat semua berjalan di luar kendali kita, baru kita sadar, betapa kita selalu dalam kuasa Allah. Allah SWT menentukan keadaan kita, some things we cannot change, ada keadaan yang di luar kuasa kita. Fokus pada reaksi kita, bagaimana kita memanfaatkan kesempatan ini? Mendekat, atau menjauh dari Allah? Karena sesungguhnya, apapun yang terjadi, bukankah ridho Allah SWT yang kita cari? Mati itu pasti, tiap hari, dengan atau tanpa Covid-19, malaikat maut mencabut nyawa atas perintah-Nya. Ini soal pilihan kita dalam menyikapi situasi. Ingat lagi tujuan kita, kemana kita kita ingin kembali?" 
Postingan ini mendapatkan respon positive dan negative dari masyarakat virtual, seperti respon yang disampaikan oleh akun @giriabdulrachman

"jin dan iblis tertawa ketika melihat manusia, sebegitu takut dengan kematian dengan wabah ini ketimbang sang pencipta-Nya, Allah SWT sehingga ibadahpun diserukan untuk dirumah, janganlah seperti itu saudaraku, tetaplah ibadah yang sudah menjadi kewajiban sebagai muslimin dan muslimat, jangan terombang ambing dengan keadaan, sadar diri akan kewajiban kepada agama sebagai pengendali anda dalam kehidupan, wallahu'alam."

Komentar dari @giriabdulrachman memberikan suatu respons yang mengingatkan kembali bahwa kuasa Allah SWT lebih besar dari pada Covid-19, sehingga perlu kiranya upaya keimanan dan berserah diri kepada Tuhan dalam menghadapi musibah tersebut. Ini menunjukkan bagaimana masyarakat dalam merespons informasi yang bernuansa keagamaan dalam anggapan positif sebagai tumpuan dalam setiap musibah. Adapun postingan lainnya yang diunggah oleh @ lambeturah_official yang disampaikan oleh Mas Menteri Pendidikan Nadim, juga tidak terlepas dari pro dan kontra dari followers seperti:

"virus corona bukan virus yang bisa diremehkan, virus corona ini sangat berbahaya dengan tingkat penularan yang sangat cepat, setiap kali seseorang keluar dari rumah, seseorang bisa mengancam nyawa orang lain, oleh karena itu, dalam upaya menyeamatkan nyawa masyarakat Indonesia untuk sementara waktu bisa bekerja dari rumah, belajar dari rumah dan ibadah dari rumah."

Pernyataan tersebut menimbulkan respons dari masyarakat virtual seperti @ibnu.hasibuan123 yang memberi komentar bahwa

"saya tidak setuju, kalau ibadahnya di rumah, gimana sih bapak ini, boleh bijak, tapi jangan kebijakan pak mentri".

Dari komentar @ibnu.hasibuan123 dan lainnya terdapat pro dan kontra terhadap pernyataannya atas menteri Kemendikbud tersebut, dimana oleh beberapa orang seperti @ranyelismapuri mengatakan di arab aja ibadah dirumah kok sekarang... jangan nyalahin mentri terus dong. Heran!. Sehingga tidak memberikan suatu bentuk pendidikan yang edukatif dan bijaksana dalam menanggapi terhadap aturan yang ditetapkan oleh pemerintah. Sementara pada akun Instagram milik@Nahdlatululama juga memberitakan postingan terhadap meninggalnya dokter dalam menghadapi Covid-19.

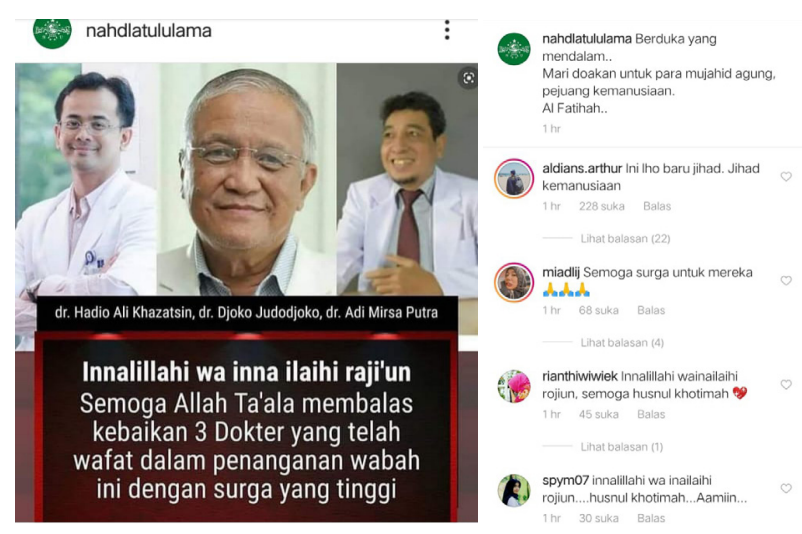

Gambar 2. Instagram Nahdlatululama

Beberapa interaksi dari setiap followers memberikan suatu bentuk dukungan dan rasa simpati yang mendalam terhadap musibah Covid-19 yang melanda Indonesia, tidak terlepas seperti komentar dari @aldians.arthur ini Iho baru jihat. Jihat kemanusiaan, selain itu @ miadlij semoga surge untuk mereka, komentar tersebut memberikan suatu rasa perhatian yang mendalam bagi masyarakat Indonesia sehingga penggunaan media Instagram lebih produktif dalam memberikan serta menanggapi setiap informasi dalam bentuk nilainilai keagamaan. Lebih lanjut dalam akun instagram @kabarmuhammadiyah juga tidak terlepas dalam memberikan pendidikan yang edukatif bagi masyarakat dengan menggunakan media instagram, dalam kasus ini salah satu postingan yang dimuat ialah: 


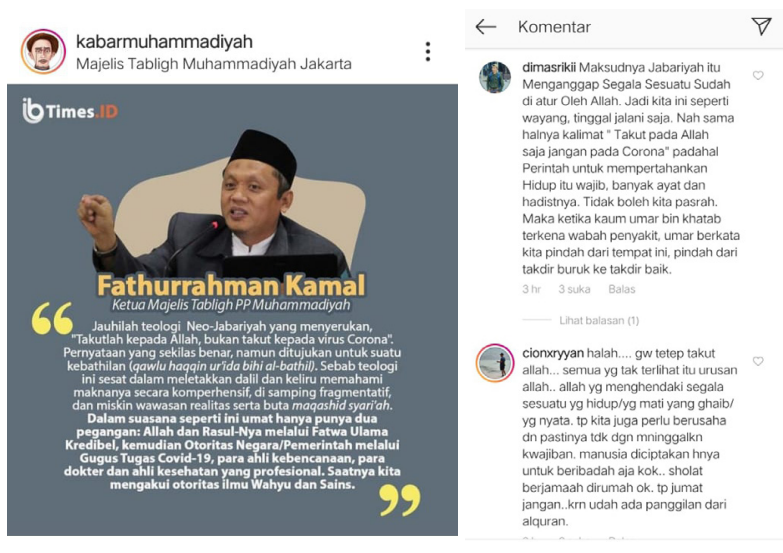

Gambar 3. Instagram KabarMuhammadiyah

Dalam akun tersebut, dimana disebarkan suatu pemahaman agar masyarakat Indonesia yang dilanda musibah Covid-19 untuk selalu berikhtiar dimana salah satu dalam ikhtiar dalam suasana seperti ini ialah dengan berpegang teguh kepada Allah dan Rasul-Nya melalui fatwa Ulama Kreadibel, kemudian otoritas Negara/pemerintahan melalui gugus tugas Covid-19, para ahli kebencanaan, para dokter dan ahli kesehatan yang semuanya itu professional secara keilmuan, dan saatnya kita mengakui otoritas ilmu Wahyu dan Sains.

Pernyataan dalam akun tersebut menjadikan suatu bentuk pengetahuan yang disampaikan melalui media sehingga cara pendidikan keagamaan virtual tersebut juga terimplementasi pada praktik-praktik bagi masyarakat secara umum dalam memahaminya, dalam artian memahami terhadap informasi keagamaan melalui media sosial instagram menjadikan suatu bentuk fresh informasi keagamaan, sehingga informasi tersebut mendapatkan respons positif dalam upaya masyarakat menghadapi Covid-19 dengan pendekatan nilai dan informasi keagamaan.

Tetapi tidak semua dalam media sosial memberikan suatu upaya ketenangan bagi masyarakat. Dilain sisi pada 17 Maret 2020 oleh CNN Indonesia merilis data terakhir dimana jangkit virus corona dinyatakan positif corona 172 orang, 5 meninggal, dan 9 sembuh, sedangkan 15 Maret 2020 berjumlah 134 orang positif corona ada kenaikan hanya beberapa hari. Sementara pada 23 Maret 2020 jumlah pasien positif corona bertambah, sehingga total pasien corona menjadi 514 orang yang dinyatakan positif terjangkit virus tersebut. Sedangkan jumlah korban meninggal dunia dan sembuh juga bertambah. Korban meninggal bertambah menjadi 10 orang, dan total mencapai 48 orang. Sedangkan jumlah pasien yang dinyatakan sembuh juga bertambah 9 orang menjadi 29 orang (Update Corona 22 Maret 514 Kasus 48 Meninggal 29 Sembuh, 2020) .

Hal ini menunjukkan adanya peningkatan pada setiap harinya, sehingga informasi yang tersebar melalui akun instagram juga mendapatkan berbagai respons dari setiap followers dalam menanggapi itu. Sehingga informasi ini memberikan suatu kepanikan bagi masyarakat, walaupun dilain sisi informasi tersebut memberikan suatu upaya bagi masyarakat untuk dapat menanggulangi covid-19. Maka akan menimbulkan reaksi sesama pengguna akun Instagram, pro dan kontra terjadi atas semua informasi yang diberikan baik oleh pemerintah, ataupun oleh akun Instagram yang bernuansa kepada informasi keagamaan. Informasi dan respon tersebut menjadi suatu bentuk reaksi sosial dalam konteks menghadapi informasi terhadap virus corona, sehingga untuk merekatkan dan mencegah kepanikan, maka literasi informasi dalam menyaring informasi yang valid dan mana yang hoax perlu untuk disampaikan, sehingga para followers lebih bijak dan pandai dalam memilah dan memilih informasi, dilain sisi informasi keagamaan dalam menyikapi Covid-19 di Indonesia juga memberi dampak yang baik bagi masyarakat, dimana adanya kesadaran masyarakat modern untuk kembali 
meningkatkan keimanan, serta banyak yang kembali mempelajari nilai-nilai agamanya, sehingga menjadikan media baru sebagai fresh informasi.

\section{E. PENUTUP}

\section{Simpulan}

Fresh informasi di instagram merupakan suatu bentuk media dalam berinteraksi menanggapi terhadap suatu postingan. Menjadi suatu realitas yang merupakan fakta dimana masyarakat virtual memanfaatkan teknologi komunikasi untuk dijadikan suatu sumber dalam belajar. Pemahaman informasi keagamaan dalam media sosial menjadi novelty yang membawa artian informasi yang bermakna, efektif dan efisien, sehingga terjadi pergeseran paradigma dalam suatu informasi menjadi fresh of informations. Dalam hasil penelitian maka ditemukan terjadinya interaksi positif dan negatif pada penggunaan instagram sebagai fresh informasi keagamaan dalam menghadapi Covid-19, dan reaksi tersebut terimplementasi pada upaya pencegahan yang dilakukan masyarakat dalam menanggulangi Covid-19 dengan kembali mencari nilai-nilai dan fatwa-fatwa keagamaan sebagai tempat bertumpu dari peristiwa itu.

Sementara beberapa informasi yang ada di media juga tidak terlepas dari hoax yang menimbulkan reaksi kecemasan dan ketakutan yang over bagi masyarakat, maka perlu adanya filter dalam suatu informasi yang disebar luas di dunia virtual. Adapun respons masyarakat virtual pada jejaring sosial media instagram mengenai fresh informasi keagamaan ialah suatu bentuk memahami konteks postingan dengan nilai keagamaan dalam menanggapi fenomena covid-19, sehingga menimbulkan pelbagai reaksi, yang pada kenyataannya reaksi tersebut memperlihatkan adanya suatu upaya masyarakat dalam memahami terhadap informasi keagamaan yang di posting, maka hal ini menimbulkan kesadaran serta rasa takut masyarakat terhadap ujian diberikan Tuhannya, sehingga mereka banyak mengupgrade keimanan dan pengetahuan keagamaan dari fenomena Covid-19 melalui media sosial instagram.

\section{Saran}

Kampanye literasi informasi media visual dalam upaya memilah dan memilih informasi yang tersebar luas di masyarakat agar masyarakat lebih selektif, kemudian hendaknya ada peningkatan keimanan dengan adanya informasi keagamaan di media sosial sehingga dapat menyikapi setiap informasi mengenai covid-19 dengan tenang dan bijak.

\section{DAFTAR PUSTAKA}

Atmoko, \& Dwi, B. (2012). Instagram Handbook. Media Kita.

Baurdrillard, J. (1983). Simulacra and simulation. Semiotext.

Dahlgren, P. (2000). Television And The Public Sphere: Citizenship, Democracy And The Media. SAGE Publications.

Holmes, D. (2005). Communication Theory: Media, Technology, and Society. Sage Publication.

Kementrian Kesehatan Republik Indonesia. (2020). Kementrian Kesehatan Republik Indonesia.

Laporan Survei Penetrasi \& Profil Perilaku Pengguna Internet Indonesia. (2018). Asosiasi Penyelenggaraan Jasa Internet Indonesia.

Nasrullah, R. (2017). Media Sosial: Perspektif Komunikasi, Budaya, dan Sosiotekniknologi. Simbiosa Rekatama Media.

Pedoman Kesiapsiagaan Menghadapi Infeksi Novel Coronavirus (2019-nCoV). (2020). Kementrian 
Kesehatan Republik Indonesia; Kementrian Kesehatan Republik Indonesia.

Pendit, P. L. (2003). Penelitian IImu Perpustakaan dan Informasi: suatu pengantar diskusi epistimologi dan metodelogi. JIP-FSUI.

Sari, M. P. (2017). Fenomena Penggunan Media Sosial Instagram Sebagai Komunikasi Pembelajaran Agama Islam. Jurnal Jom Fisip, 4(2), 5-6.

Sugihartini, R. (2014). Perkembangan masyarakat Informasi dan teori sosial kontenporer. Prenadamedia Group.

Sugiyono. (2017). Metode Penelitian Kombinasi (mixed methods). Alfabeta.

Update corona 22 maret 514 kasus 48 meninggal 29 sembuh. (2020). https://www.cnnindonesia. com/nasional/20200322145049-20-485799/ update-corona-22-maret-514-kasus48-meninggal-29-sembuh?utm_ campaign=cnnsocmed\&utm medium=oa\&utm_source=instagram\&utm_ content=igstory

Van Djik, J. (2006). The Network Society. Thousandoaks. Sage Publications. 
